\title{
Stakeholders Evaluation of Staff Teaching General Nursing Branch at Health Technical Institute
}

\author{
${ }^{1}$ Prof. Dr. Yasser Mohammed El-Wazir, ${ }^{2}$ Assistant prof. Fathyya Abdelrazek Afify, \\ ${ }^{3}$ Shereen Megahed Koutta \\ ${ }^{1}$ Prof of Physiology, Faculty of Medicine-Suez Canal University, ${ }^{2}$ Assistant Prof of Nursing \\ Administration, Faculty of Nursing - Suez Canal University, ${ }^{3}$ BSc. Nursing Administration- \\ Suez canal University 1998.
}

\begin{abstract}
Background: Curriculum development for nursing in Health Technical Institute (HTI) becomes a needed issue as a second level of nursing education in Egypt in a scarce nursing labor market. The aim: of this study was to evaluate staff teaching general nursing branch. research Design was comparative study design was utilize in this study Settings the study was carried out in Health Technical in Port Said Sample a Purposive sample was followed in the present study. The study subjects consisted of 76 stakeholders, whom are students (undergraduate and graduates of HTI), internal and external educators. The tool that was used for data collection was staff teaching Evaluation Questionnaire. Results: The study results indicated that teaching staff often caring about students successful scored the highest percentage; whereas rarely there is committee to evaluate teaching staff periodically. Conclusion: It was concluded that no committee to evaluate teaching staff of general nursing branch at Health Technical Institute periodically. Recommendations: It was recommended that teaching staff should be revise for participating them in planning and revising courses, improve their knowledge practice and evaluating them by committee periodically are recommended for target development
\end{abstract}

Key words: Curriculum development, teaching staff, stakeholders 


\section{INTRODUCTION}

A great course is more likely the result of a long continuous effort of thinking, researching and reflecting upon the issue of what is the purpose of the course, who are the learners and what constitutes learning, what method of instruction are suitable and how does he implement them in a given context, what assessment procedure are appropriate, what content should be included and how should the course be evaluated.

\{1\}By recording these ideas in a document, they can be shared with colleagues, students and other stakeholders so that they can contribute to further planning and development of the courses. Consequently, the gap between best practice in planning and individual practice is not an unreachable chasm, but merely a journey one can take to improve the quality of teaching and learning in any university.

\{2\}Educators are not engineers applying their skills to carry out a plan or drawing, they are artists who are able to improvise and devise new ways of looking at things. We have to work within a personal but shared idea of the 'good' - an appreciation of what might make for human flourishing and well-being .

\{3\}Effective classroom teacher is kind, generous, listen to students, and encourages them has faith in students, keep confidential matters, likes teaching their subjects, take time to explain things, help students when they are in stuck, tell students how they are doing, allow students to have their say, don't give up on students, care for student's opinions, makes them feel clever, treat people equally, stand up for you, make allowances, tell the truth and are forgiving. Teacher must create opportunities for learner to become more skilled, more able, and more powerful.

\{4\}Students are the hub around which the educational wheel turns, every philosophy and/or conceptual framework must be responding to the individual needs of students: physical, social, psychological, and educational. Curriculum workers and instruction personnel know that they cannot ignore interests and wants of students for these can be powerful motivation. Active participation during lecture, discussion, questioning, redemonestration and even listening is considered an implementation role of the student in curriculum. Student self-evaluation, peer evaluation, teacher evaluation, content evaluation, and school evaluation all determine the evaluation role of the student. 
\{5\} Abruzzese1992 described process evaluation as a happiness index. While teaching and learning are ongoing, learners are asked their opinions about faculty, learning $\backslash$ course objectives, content, teaching and learning methods, physical facilities, and administration of the learning experience. All educators; particular nurse educators have to be aware of their own beliefs and values about the teaching-learning process and about their students.

\{6\} it is important to consider students nurse characteristics for effective teaching. These students' nurses have the right to be prepared as future nurses capable of ethically caring for patients, and able to deal with real life situations.

\{7\}In any review or evaluation there may be varying degree of participation by stakeholders. High participatory evaluation implies that the stakeholders help to determine what is to be evaluated, how it should be evaluated and how the findings should be used. Stakeholders must have better knowledge of the peculiarities or contextual factors that impact on a curriculum, Stakeholders may be include past and present students, colleagues, and educational leaders $\{8\}$.As a result of this great effect of educators, this study is geared to evaluate staff teaching general nursing branch at Health Technical Institute (HTI) in port-said from the point of view of stakeholders

Significance of the Study: Staff teaching assists the student to progress form a state of dependence toward a state of independence. He has the first-hand to graduate high qualified nurse.

\section{THE AIM STUDY:}

To evaluate staff teaching general nursing branch.

\section{SUBJECTS AND METHODS:}

\section{Technical design:}

Research Design: A Comparative research design.

Setting: The study was conducted in Port Said City at health technical institute

Subjects: all undergraduates 27, graduates 35 and 14 educator's (internal 8 \& external 6) as a total 76 stakeholders. 
Tool for data collection: Data for this study were collected using Staff Teaching Evaluation Questionnaire (STQ) which consisted of two parts: Part (I) was geared to collect data about the Socio-demographic characteristics i.e., age, sex, years of experience, extra, Part (II) was developed based on Flifel (2009) \{9\} and Noel Levitz (2000)\{10\} in addition to other literature review. It is consisted of two parts (1) Teaching Staff: It covered teaching staff evaluation which included seven statements with a five-point frequency scale (always $=5$, often $=4$, sometimes $=3$, rarely=2 and never=1). (2)Teaching Skills: It covered teaching skills evaluation which was composed of two components; classroom presentation and clinical demonstration. It included nineteen statements with a five-point frequency scale (always $=5$, often $=4$, sometimes $=3$, rarely $=2$ and never $=1$ ).

\section{II- OPERATIONAL DESIGN}

The operational design included preparatory phase, content validity, pilot study and fieldwork.

\section{1-Preparatory Phase}

It included reviewing of literatures related to the research problem and theoretical knowledge of various aspects of it using different scientific references to modify the tool of data collection.

\section{2-Content Validity}

It was done by jury of 5 expertise of professors from (1) the administration department, faculty of nursing at Port Said University ; (1) psychiatric department, faculty of nursing at Ain Shams University; (3) medical education department, faculty of medicine at Suez Canal University. The jury revised the tool off data collection for clarity, relevance, comprehensiveness, understanding, and ease for implementation. The modifications were done according to their opinion.

\section{3-Pilot Study}

Pilot Study was conducted on $10 \%$ of subjects excluded from the sample. It was done to test the clarity and practicality of the tool. Accordingly, the needed modifications were done and the final form was developed. 


\section{4-Field Work Description}

The study was conducted along one year started from April, 2013 to March 2014. The data were collected from undergraduates and graduates of HTI after explaining the Staff teaching Evaluation Questionnaire items at available time of them. The researcher remained with the students until questionnaires were completed to ensure objectivity of the responses and to check that all items were answered. Whereas the data were collected from internal educators and some external educators in HTI at break time and some of them fulfilled their questionnaire in their workplace in the morning, every other day for about 2 hours.

\section{III- ADMINISTRATIVE DESIGN:}

Permissions through formal agreement of directors of HTI were obtained to carry out the study. Then the aim of the study was explained to all stakeholders included in the study after taking their permission to participate.

\section{Ethical Considerations:}

Agreement of the subjects was taken with the opportunity to draw from the study at any time. They were also assured that the collected information would be treated confidentially and used for the research purpose only.

\section{IV-STATISTICAL ANALYSIS:}

Data entry and statistical analysis was carried out using SPSS 18.0 Statistical software package. Quality control was done at the stages of coding and data entry. Data was represented using descriptive statistics in the form of numbers and percentages for qualitative variables, means and standard deviations, T-test, F-test for quantitative variables and X2 for qualitative. Statistical significance was considered at $\mathrm{P} \leq 0.05$.

\section{Limitations of the Study:}

Some of staff teaching refused to participate in the study. In general, the number of stakeholder groups was low. However, all subjects were included. 


\section{RESULTS:}

Table (1): shows socio-demographic characteristics of students, as regards to age, most of them $(83.9 \%)$ their age ranged from 20years to less than 22 years, while only $1.6 \%$ of them their age were less than 20years with mean age of $20.7 \pm 0.9$ year.

Table (2): shows socio-demographic characteristics of educators, as regard to age, most of them (71.4\%) their age ranged from 30years to less than 40 years, while only $14.3 \%$ of them their age ranged from 20years to less than 30years and ranged from 40years to more than 50, with mean age of 34.9 \pm 5.4 year. Furthermore, their Duration of experience (years) two third of them $(64.3 \%)$ ranged from 1 year to less than 5years, the remaining percent $(35.7 \%)$ more than 5years to 10 years, with mean experience of $3.9 \pm 1.7$ years.

Table (3): show the evaluation of teaching staff from the point view of stakeholders, regarding teaching staff often caring about students successful scored the highest percentage $85.7 \%$ among educators and $75.8 \%$ among students, with no statistical significant difference. Whereas, rarely there is committee to evaluate teaching staff periodically scored the highest percentage $85.7 \%$ among educators and $41.9 \%$ among students. With statistical significant difference.

Table (4): shows the evaluation of teaching skills from the point view of stakeholders, regarding teaching staff often maintain eye contact, and score the highest percentage $77.4 \%$ among students and $100 \%$ among educators. With no statistical significant difference. Also, it was noticed that teaching staff often starts classroom presentation by an effective introduction scored the highest percentage $100 \%$ among educators and $64.5 \%$ among students. With statistical significant difference.

Table (5): shows the evaluation of teaching skills from the point view of stakeholders, regarding to encourage participants to practice, it was noticed that scored the highest percentage $83.9 \%$ among students and $90 \%$ among educators. With no statistical significant difference. Whereas uses checklists for evaluation scored the highest percentage 100\% among educators and $67.6 \%$ among students. with no statistical significant difference. 
Table 1: Socio-demographic characteristics of the students

\begin{tabular}{|c|c|c|}
\hline \multirow{2}{*}{ Socio-demographic characteristics } & \multicolumn{2}{|c|}{ Studied students(n=62) } \\
\hline & No. & $\%$ \\
\hline Age (years) & & \\
\hline Less than 20 & 1 & (1.6) \\
\hline $20-$ & 52 & (83.9) \\
\hline $22-<24$ & 9 & 14.5 \\
\hline $\begin{array}{l}\text { Min-Max } \\
\text { Mean } \pm \text { SD }\end{array}$ & \multicolumn{2}{|c|}{$\begin{array}{l}19.0-23.0 \\
(\mathbf{2 0 . 7} \pm \mathbf{0 . 9})\end{array}$} \\
\hline Educational level & & \\
\hline Nursing Faculty & 35 & 56.5 \\
\hline Nursing institute & 27 & 43.5 \\
\hline $\begin{array}{l}\text { Grade } \\
\text { Second academic year in HTI. }\end{array}$ & 27 & 43.5 \\
\hline $\begin{array}{l}\text { Second academic year in faculty of } \\
\text { nursing }\end{array}$ & 15 & 24.2 \\
\hline $\begin{array}{l}\text { Third academic year in faculty of } \\
\text { nursing. }\end{array}$ & 9 & $(14.5)$ \\
\hline $\begin{array}{l}\text { Forth academic year in faculty of } \\
\text { nursing. }\end{array}$ & 11 & 17.7 \\
\hline
\end{tabular}


Table (2): Socio-demographic characteristics of the educators.

\begin{tabular}{|c|c|c|}
\hline \multirow{2}{*}{ Socio-demographic characteristics } & \multicolumn{2}{|c|}{ Studied educators $(n=14)$} \\
\hline & No. & $\%$ \\
\hline Age (years) & & \\
\hline $20-$ & 2 & 14.3 \\
\hline $\begin{array}{l}30- \\
40-<50\end{array}$ & $\begin{array}{c}10 \\
2\end{array}$ & $\begin{array}{c}(71.4) \\
14.3\end{array}$ \\
\hline Min-Max & \multirow{2}{*}{\multicolumn{2}{|c|}{$\begin{array}{c}29-48 \\
(\mathbf{3 4 . 9} \pm \mathbf{5 . 4})\end{array}$}} \\
\hline Mean \pm SD & & \\
\hline Educational level & & \\
\hline Nursing technician & 1 & 7.1 \\
\hline Nursing Bachelor & 4 & 28.6 \\
\hline Master & 5 & 35.7 \\
\hline PHD & 4 & 28.6 \\
\hline \multicolumn{3}{|l|}{ Job } \\
\hline Assistant lecturer & 2 & 14.3 \\
\hline Lecturer & 3 & 21.4 \\
\hline Nursing technician & 7 & 50.0 \\
\hline Nursing specialist & 1 & (7.1) \\
\hline Professor & 1 & (7.1) \\
\hline $\begin{array}{l}\text { Duration of experience (years) } \\
1-\end{array}$ & 9 & (64.3) \\
\hline $5-<10$ & 5 & 35.7 \\
\hline $\begin{array}{l}\text { Min-Max } \\
\text { Mean } \pm \text { SD }\end{array}$ & \multicolumn{2}{|c|}{$\begin{array}{c}1-7 \\
(\mathbf{3 . 9} \pm \mathbf{1 . 7}) \\
\end{array}$} \\
\hline $\begin{array}{l}\text { Attending training courses } \\
\text { No }\end{array}$ & 5 & 35.7 \\
\hline Yes & 9 & 64.3 \\
\hline \#Type of training courses [ $n=9]$ & & \\
\hline Preparing teachers & 7 & 77.8 \\
\hline Teaching methods & 3 & 33.3 \\
\hline Quality of education & 3 & 33.3 \\
\hline Problem solving & 2 & 22.2 \\
\hline Computer & 2 & 22.2 \\
\hline $\begin{array}{l}\text { Duration since last training (years) } \\
{[n=9]}\end{array}$ & & \\
\hline Less than 5 & 8 & 88.9 \\
\hline 5- & 0 & 0.0 \\
\hline $10-$ & 1 & 11.1 \\
\hline
\end{tabular}


Table (2): Socio-demographic characteristics of the educators.... (cont.)

\begin{tabular}{|l|c|c||}
\hline \multirow{2}{*}{\multicolumn{1}{|c|}{ Socio-demographic characteristics }} & \multicolumn{2}{|c||}{ (ntudied educators } \\
\cline { 2 - 3 } & No. & $\%$ \\
\hline \# Taught courses at HTI & & \\
Fundamental and community health nursing & 2 & 14.3 \\
Child and maternity nursing & 3 & 21.4 \\
Medical sociology & 1 & 7.1 \\
Educational technology & 4 & 28.6 \\
English & 2 & 14.3 \\
Epidemiology & 2 & 14.3 \\
Anatomy & 1 & 7.1 \\
Path physiology & 1 & 7.1 \\
Pharmacology & 2 & 14.3 \\
Nutrition & 1 & 7.1 \\
Infection control & 2 & 14.3 \\
Adult nursing & 2 & 14.3 \\
Applied clinical nutrition & 1 & 7.1 \\
Psychic nursing & 3 & 21.4 \\
Geriatric nursing & 3 & 21.4 \\
Administration & $\mathbf{1}$ & $\mathbf{7 . 1}$ \\
\hline
\end{tabular}


Table (3): Evaluation of teaching staff from the point view of HTI stakeholders.

\begin{tabular}{|c|c|c|c|c|c|c|c|c|c|c|c|c|c|}
\hline \multirow{3}{*}{$\begin{array}{c}\text { Teaching staff } \\
\text { evaluation }\end{array}$} & \multicolumn{6}{|c|}{ Students $(n=62)$} & \multicolumn{6}{|c|}{ Educators $(n=14)$} & \multirow{3}{*}{$\begin{array}{c}\text { Sig.(P) } \\
\\
\mathbf{X}^{2}\end{array}$} \\
\hline & \multicolumn{2}{|c|}{ rare } & \multicolumn{2}{|c|}{$\begin{array}{c}\text { Someti } \\
\text { mes }\end{array}$} & \multicolumn{2}{|c|}{ often } & \multicolumn{2}{|c|}{ rare } & \multicolumn{2}{|c|}{$\begin{array}{c}\text { Someti } \\
\text { mes }\end{array}$} & \multicolumn{2}{|c|}{ often } & \\
\hline & No & $\%$ & No & $\%$ & No & $\%$ & No & $\%$ & No & $\%$ & No & $\%$ & \\
\hline $\begin{array}{l}\text { Teaching staff gives } \\
\text { complete caring and } \\
\text { helping to students. }\end{array}$ & 3 & 4.8 & 11 & 17.7 & 48 & 77.4 & 0 & 0.0 & 4 & 28.6 & 10 & 71.4 & 0.494 \\
\hline $\begin{array}{l}\text { Teaching staff is available } \\
\text { at any time. }\end{array}$ & 7 & 11.3 & 5 & 8.1 & 50 & 80.6 & 3 & 21.4 & 1 & 7.1 & 10 & 71.4 & 0.598 \\
\hline $\begin{array}{l}\text { Teaching staff is caring } \\
\text { about students successful. }\end{array}$ & 8 & 12.9 & 7 & 11.3 & 47 & 75.8 & 0 & 0.0 & 2 & 14.3 & 12 & $\underline{85.7}$ & 0.361 \\
\hline $\begin{array}{l}\text { Teaching staff knows } \\
\text { about student's mental } \\
\text { ability. }\end{array}$ & 14 & 22.6 & 12 & 19.4 & 36 & 58.1 & 1 & 7.1 & 4 & 28.6 & 9 & 64.3 & 0.384 \\
\hline $\begin{array}{l}\text { Teaching staff answers } \\
\text { student's question. }\end{array}$ & 5 & 8.1 & 7 & 11.3 & 50 & 80.6 & 0 & 0.0 & 3 & 21.4 & 11 & 78.6 & 0.363 \\
\hline $\begin{array}{l}\text { Helping of teaching staff } \\
\text { enough for students needs. }\end{array}$ & 7 & 11.3 & 15 & 24.2 & 40 & 64.5 & 1 & 7.1 & 4 & 28.6 & 9 & 64.3 & 0.872 \\
\hline $\begin{array}{l}\text { There is committee to } \\
\text { evaluate teaching staff } \\
\text { periodically. }\end{array}$ & 26 & 41.9 & 13 & 21.0 & 23 & 37.1 & 12 & $\underline{85.7}$ & 0 & 0.0 & 2 & 14.3 & $0.010^{*}$ \\
\hline
\end{tabular}


Table (4): Evaluation of teaching skills from the point view of HTI stakeholders regarding to classroom presentation skills.

\begin{tabular}{|c|c|c|c|c|c|c|c|c|c|c|c|c|c|}
\hline \multirow{3}{*}{$\begin{array}{l}\text { Class room presentation } \\
\text { skills }\end{array}$} & \multicolumn{6}{|c|}{ Students $\quad(n=62)$} & \multicolumn{6}{|c|}{ Educators $(n=14)$} & \multirow{3}{*}{$\begin{array}{c}\text { Sig.(P) } \\
\mathbf{X}^{2}\end{array}$} \\
\hline & \multicolumn{2}{|c|}{ Rare } & \multicolumn{2}{|c|}{$\begin{array}{c}\text { Someti } \\
\text { me }\end{array}$} & \multicolumn{2}{|c|}{ Often } & \multicolumn{2}{|c|}{ Rare } & \multicolumn{2}{|c|}{$\begin{array}{c}\text { Someti } \\
\text { me }\end{array}$} & \multicolumn{2}{|c|}{ Often } & \\
\hline & $\begin{array}{l}\text { No } \\
.\end{array}$ & $\%$ & $\begin{array}{c}\text { No } \\
\text {. }\end{array}$ & $\%$ & No & $\%$ & No & $\%$ & $\begin{array}{c}\text { No } \\
\text {. }\end{array}$ & $\%$ & $\begin{array}{c}\text { No } \\
.\end{array}$ & $\%$ & \\
\hline $\begin{array}{l}\text { Starts by an effective } \\
\text { introduction. }\end{array}$ & 8 & $\begin{array}{c}12 . \\
9\end{array}$ & 14 & $\begin{array}{c}22 . \\
6\end{array}$ & 40 & $\frac{64 .}{5}$ & 0 & 0.0 & 0 & 0.0 & 14 & $\frac{10}{\underline{0.0}}$ & $0.030^{*}$ \\
\hline $\begin{array}{l}\text { Starts by objectives as a } \\
\text { part of introduction. }\end{array}$ & 9 & $\begin{array}{c}14 . \\
5\end{array}$ & 19 & $\begin{array}{c}30 . \\
6\end{array}$ & 34 & $\begin{array}{c}54 . \\
8\end{array}$ & 0 & 0.0 & 2 & $\begin{array}{c}14 . \\
3\end{array}$ & 12 & $\begin{array}{c}85 . \\
7\end{array}$ & 0.085 \\
\hline $\begin{array}{l}\text { Maintain clear voice for } \\
\text { all participants. }\end{array}$ & 4 & 6.5 & 17 & $\begin{array}{c}27 . \\
4\end{array}$ & 41 & $\begin{array}{c}66 . \\
1\end{array}$ & 0 & 0.0 & 2 & $\begin{array}{c}14 . \\
3\end{array}$ & 12 & $\begin{array}{c}85 . \\
7\end{array}$ & 0.314 \\
\hline Maintain eye contact. & 6 & 9.7 & 8 & $\begin{array}{c}12 . \\
9\end{array}$ & 48 & $\frac{77 .}{4}$ & 0 & 0.0 & 0 & 0.0 & 14 & $\begin{array}{l}\underline{10} \\
\underline{0.0}\end{array}$ & 0.144 \\
\hline $\begin{array}{l}\text { Provide positive } \\
\text { feedback. }\end{array}$ & 9 & $\begin{array}{c}14 . \\
5\end{array}$ & 16 & $\begin{array}{c}25 . \\
8\end{array}$ & 37 & $\begin{array}{c}59 . \\
7\end{array}$ & 0 & 0.0 & 1 & 7.1 & 13 & $\begin{array}{c}92 . \\
9\end{array}$ & 0.057 \\
\hline $\begin{array}{l}\text { Responds to participants } \\
\text { questions. }\end{array}$ & 6 & 9.7 & 13 & $\begin{array}{c}21 . \\
0\end{array}$ & 43 & $\begin{array}{c}69 . \\
4\end{array}$ & 0 & 0.0 & 1 & 7.1 & 13 & $\begin{array}{c}92 . \\
9\end{array}$ & 0183 \\
\hline $\begin{array}{l}\text { Displays a positive use of } \\
\text { humor. }\end{array}$ & 11 & $\begin{array}{c}17 . \\
7\end{array}$ & 23 & $\begin{array}{c}37 . \\
1\end{array}$ & 28 & $\begin{array}{c}45 . \\
2\end{array}$ & 0 & 0.0 & 1 & 7.1 & 13 & $\begin{array}{c}92 . \\
9\end{array}$ & $0.005 *$ \\
\hline $\begin{array}{l}\text { Ends by effective } \\
\text { summary. }\end{array}$ & 15 & $\begin{array}{c}24 . \\
2\end{array}$ & 14 & $\begin{array}{c}22 . \\
6\end{array}$ & 33 & $\begin{array}{c}53 . \\
2\end{array}$ & 0 & 0.0 & 1 & 7.1 & 13 & $\begin{array}{c}92 . \\
9\end{array}$ & $0.021 *$ \\
\hline
\end{tabular}


Table (5): Evaluation of teaching skills from the point view of HTI stakeholders regarding to clinical demonstration.

\begin{tabular}{|c|c|c|c|c|c|c|c|c|c|c|c|c|c|}
\hline \multirow{3}{*}{$\begin{array}{c}\text { CLINICAL } \\
\text { DEMONSTATION. }\end{array}$} & \multicolumn{6}{|c|}{ STUDENTS $(\mathrm{N}=62)$} & \multicolumn{6}{|c|}{ EDUCATORS $(\mathrm{N}=14)$} & \multirow{3}{*}{$\begin{array}{c}\text { SIG. } \\
(\mathrm{P}) \\
\mathrm{X}^{2}\end{array}$} \\
\hline & \multicolumn{2}{|c|}{ Rare } & \multicolumn{2}{|c|}{$\begin{array}{c}\text { Someti } \\
\text { me }\end{array}$} & \multicolumn{2}{|c|}{ Often } & \multicolumn{2}{|c|}{ Rare } & \multicolumn{2}{|c|}{$\begin{array}{c}\text { Someti } \\
\text { me }\end{array}$} & \multicolumn{2}{|c|}{ Often } & \\
\hline & $\begin{array}{c}\text { No } \\
\text {. }\end{array}$ & $\%$ & $\begin{array}{c}\text { No } \\
\text {. }\end{array}$ & $\%$ & No & $\%$ & No & $\%$ & No & $\%$ & No. & $\%$ & \\
\hline $\begin{array}{l}\text { Starts by an effective } \\
\text { introduction. }\end{array}$ & 7 & 11.3 & 8 & 12.9 & 47 & 75.8 & 0 & 0.0 & 0 & 0.0 & 10 & $\begin{array}{c}100 . \\
0\end{array}$ & 0.217 \\
\hline $\begin{array}{l}\text { Arranges demonstration } \\
\text { area. }\end{array}$ & 8 & 12.9 & 9 & 14.5 & 45 & 72.6 & 1 & 10 & 0 & 0.0 & 9 & 90.0 & 0.395 \\
\hline $\begin{array}{l}\text { Demonstrates all steps of } \\
\text { procedure. }\end{array}$ & 5 & 8.1 & 6 & 9.7 & 51 & 82.3 & 0 & 0.0 & 0 & 0.0 & 10 & $\begin{array}{c}100 . \\
0\end{array}$ & 0.217 \\
\hline $\begin{array}{l}\text { Uses simulated models } \\
\text { such as dolls. }\end{array}$ & 4 & 6.5 & 7 & 11.3 & 51 & 82.3 & 0 & 0.0 & 0 & 0.0 & 10 & $\begin{array}{c}100 . \\
0\end{array}$ & 0.395 \\
\hline $\begin{array}{l}\text { Asks and encourages } \\
\text { questions. }\end{array}$ & 6 & 9.7 & 11 & 17.7 & 45 & 72.6 & 0 & 0.0 & 0 & 0.0 & 10 & $\begin{array}{c}100 . \\
0\end{array}$ & 0.351 \\
\hline $\begin{array}{l}\text { Maintain clear voice for all } \\
\text { participants. }\end{array}$ & 6 & 9.7 & 10 & 16.1 & 46 & 74.2 & 0 & 0.0 & 0 & 0.0 & 10 & $\begin{array}{c}100 . \\
0\end{array}$ & 0.351 \\
\hline $\begin{array}{l}\text { Encourages participants to } \\
\text { practice. }\end{array}$ & 7 & 11.3 & 3 & 4.8 & 52 & $\underline{83.9}$ & 0 & 0.0 & 1 & 10 & 9 & $\underline{90.0}$ & 0.454 \\
\hline $\begin{array}{l}\text { Observes participants } \\
\text { during practice. }\end{array}$ & 6 & 9.7 & 6 & 9.7 & 50 & 80.6 & 0 & 0.0 & 0 & 0.0 & 10 & $\frac{100 .}{\underline{0}}$ & $\underline{0.313}$ \\
\hline Provide positive feedback. & 9 & 14.5 & 5 & 8.1 & 48 & 77.4 & 0 & 0.0 & 1 & 10 & 9 & 90.0 & 0.436 \\
\hline $\begin{array}{l}\text { Uses checklists for } \\
\text { evaluation. }\end{array}$ & 7 & 11.3 & 13 & 21.0 & 42 & $\underline{67.7}$ & 0 & 0.0 & 0 & 0.0 & 10 & $\frac{100 .}{\underline{0}}$ & 0.107 \\
\hline Maintain eye contact & 6 & 9.7 & 11 & 17.7 & 45 & 72.6 & 0 & 0.0 & 0 & 0.0 & 10 & $\begin{array}{c}100 . \\
0\end{array}$ & 0.166 \\
\hline
\end{tabular}




\section{DISCUSSION:}

Regarding to socio-demographic characteristics, the current study results showed that most of students their age ranged between 20years and less than 22 years, educators age ranged from 30years to less than 40 years, with experience (years) ranged from 1year to less than 5years, academic leaders their age ranged from 30 years to less than 40 years, with experience ranged from 10 years to less than 15 years, health authority leaders their age ranged from 35 years to less than 40 years, their experience ranged from 10 years to less than 15 years. These different ages of stakeholders extended from lower age of students to higher age of health authority leaders with different level of experience help in comprehensive and more effective evaluation of all curriculum aspects. This is assured by $\{\mathbf{1 1}\}$ who showed that effective evaluation should include many evaluators /teams who understand the social context and the unique substance of the evaluation object and possessing extensive competencies in research methodology and other data analysis techniques. Regarding evaluation of teaching staff, the results of the present study indicated that the most of stakeholders reported that teaching staff often caring about students successful. This is a needed character for teaching staff that may affect positively the learnerteacher relationship and interaction and hence effective role of teacher in facilitating learning, as students who have positive relationships with their teachers are more likely to perceive the classroom environments in positive way $\{\mathbf{1 2}\}$. This is supported by $\{\mathbf{1 3}\}$ who globally indicated to the emotional nature of humans and how it could have a lot to do with teacher-student interaction, activities associated with success, and the topic being taught. Furthermore, the present study showed that highest percentages of stakeholders reported that there is rarely a committee to evaluate teaching staff periodically. This is a common problem not only the moderate and higher levels of nursing education but also in all health professionals' education, as evaluation is one of the high performance keys in addition to continuous staff development $\{\mathbf{1 4}\}$. Concerning evaluation of teaching skills in relation to class room presentation skills, the current results revealed that highest percentages of stakeholders reported that teaching staff often starts classroom presentation by an effective introduction. So, teaching staff will have student's attention and motivate them to participate in learning activity. This is in agreement with $\{\mathbf{1 5}\}$ on study conducted on nursing faculty members. Also, the current study result is supported by $\{\mathbf{1 6}\}$ who indicated to the importance of starting by an effective introduction as a presentation skill. In addition, the present study revealed that the highest percentages of stakeholders stated that teaching staff often maintain eye contact. Maintaining eye contact improves nonverbal 
communication between teacher and learner, so enhance teaching skill. This result is in accordance with $\{\mathbf{1 7}\}$ who indicated to the effect of eye contact in significant improvement students' learning. Regarding evaluation of teaching skills in relation to clinical demonstration, the present study revealed that higher percentages of stakeholders reported that teaching staff often encourage participants to practice. Clinical demonstration must be practiced by participants because it is depending on psychomotor domain, so participants will be more skillful. This finding is supported by $\{\mathbf{1 8}\}$ who indicated to effective teacher must create opportunities for learner to become more skilled, abler, and more powerful. Moreover, the present study showed higher percentages of stakeholders reported that checklists used for evaluation of clinical demonstration. Observation checklists used for assessing students' performance in the lab. These result assured by $\{\mathbf{1 9}\}$ who stated that observation checklists are often used to assess student performance in lab activities as a quick way of assessing specific skills, or attitudes for several students over a short time.

\section{CONCLUSION}

Based on the findings of the present study, it can be concluded that: Around seventies percentages and more of students and educators indicated to application of criteria for good staff and teaching skills: Teaching staff is caring about student's successful, started classroom presentation by effective introduction and maintain eye contact, encourage participants to practice, uses checklists for evaluation and No committee to evaluate teaching staff periodically.

\section{RECOMMENDATIONS}

Teaching staff should be revising for participating them in planning and revising courses that they are taught, evaluating teaching staff by Committee from Ministry of Health periodically, Improve their knowledge \& practice by attending those training courses encourage them to attending national and international conference. 


\section{REFERENCES:}

\{1\} Albakoor, F.A. (2008): Relationship between the educational environment and nursing students self-esteem. Unpublished thesis, MSc. Alex. Alexandria: University of Alexandria, Nursing Faculty.

\{14\} Afify, F.A. (2004): study of absenteeism and factors contributing to it among head and staff nurses. Unpublished thesis, Suez Canal Un., Fac. Ng., M.Sc, 29, 182, 184, $188 .$.

\{15\} Alfouly, O. (2004): The professional ethical awareness among nurse educators at faculties of nursing. Unpublished thesis. MSc. Alex. Alexandria: University of Alexandria, Nursing Faculty.

\{12\} Cheung, L. (2008): Presentation skills.Purdue University (West Lafayette, India, USA) the internet TESL JournalixIV(6) at:http://iteslj/Techniques/cheung.presentation skills.html \{16\}Dent, J.A. and Harden, R.M. (2005): A Practical Guide For medical Teachers, $2^{\text {nd }}$ ed., London: Elsevier Churchill Living stone, 10-15.

\{9\} Flifel, H.M. (2009): Nurse educator's opinions about the nursing courses curricula of the secondary technical schools of nursing. Unpublished thesis, Alexandria Un., Fac. Ng., M.sc., 4,6.

\{2\} Grady, G. (2001): Curriculum design (designing \& planning a successful course). 4 (6); available at: http://www.cdtl.nus.edu/ brief/v4n6/ default.htm

\{6\} Harris, L., Driscoll, P., Lewis, L., Matthews, L. and Russell, c. (2010): Assessment \& Evaluation in Higher Education.35 (4). Taylor Francis online, article view: 375. Available at: http://www.tandfonline.com

\{3\} Jeffs, M. and Smith, K. (2005): Informal Education. Conversation, democracy and learning 3e, Nottingham: Educational Heretics Press. 'Evaluation' in the encyclopaedia of informal education, available at: www.infed.org/biblio/b-eval.htm

\{7\} Keating, S.B. (2006): Curriculum development and evaluation in Nursing. London: Lippincott Williams\& Wilkins 160-162, 260-262.

\{17\}Kelly, A.V. (2009): The Curriculum Theory and Practice. 6th ed, London: Sage Publication, 137-140. 
\{19\} Kelsner, M.(2001): Teacher rolein curriculum Maricopa Center for Learning and Instruction (mcli);at: http://edaff.siumed.edu/DEPT/Index.htm

\{13\} Lachini, A., Beets, M., Ball, M. and Loman, M. (2011): Curriculum development and evaluation in nursing. 2nd ed., published in Springer publishing company, New York.

$\{10\}$ Noel-Levitz (2000) : Adult Students Priorities Survey. Mark Reflex. Scantron publisher.

\{4\} Smith, M.K. (2006): Evaluation - theory and practice. 'Evaluation' in the encyclopedia ofinformal education, available at: www.infed.org/ biblio/b-eval.htm.

$\{8\}$ Uys, L.R. and Gwele, N.S. (2005): Curriculum development in nursing. London: Taylor \& Francis Group 76- 79, 111-117.

\{5\} Walker, D.F. (2003): Fundamentals of curriculum: Passion and Professionalism. 2nd ed., London: Lawrence Erlbaum Associates, Publishers, P.p. 5, 6.

$\{11\},\{18\}$ Wise, D. (2008): Curriculum evaluation. University Of Exeter PGCE (PCE). 2nd ed., Boston: Kluwer Academic Publishers. P.p.7-9.

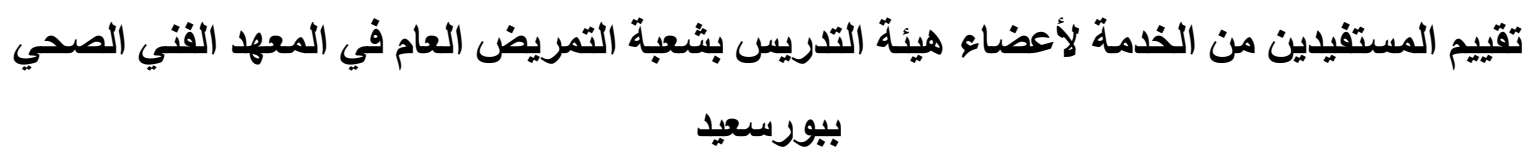

$$
\begin{aligned}
& \text { أ.د/ ياسر محمد الوزير ، د/ فتحية عبد الرازق عفيفي ، شيرين مجاهد محمد قوطة } \\
& \text { أستاذ ا لفسيولوجى بكلية الطب جامعة قناة السويس، مدرس مساعد بقسم ادارة التمريض جامعة قناة السويس، }
\end{aligned}
$$

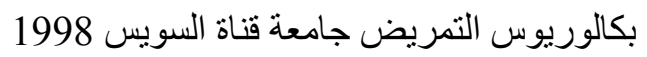

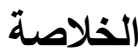

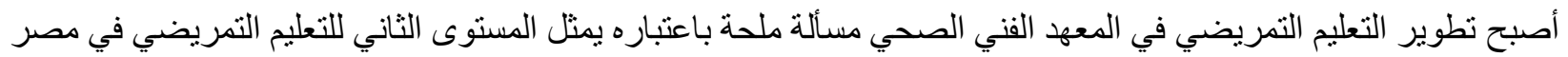

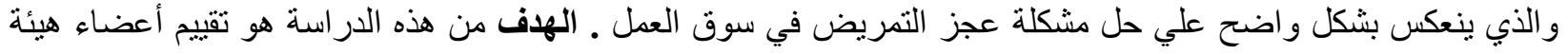

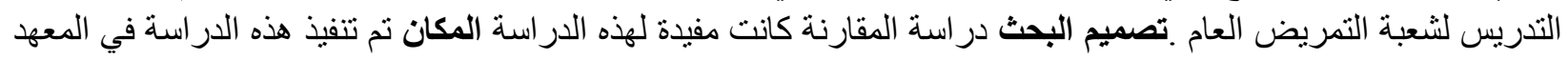

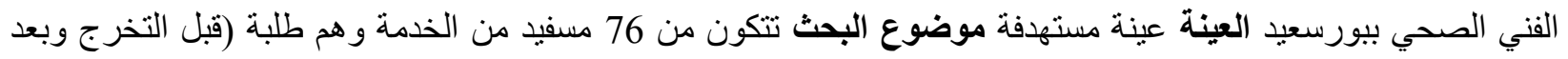
التخرج من المعهد الفني الصحي) و مدرسين تعاقد داخلى ونعاقد خارجي. أداة البحث هي تجميع البيانات باستخدام استبيان

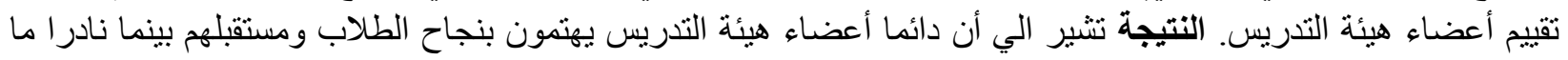

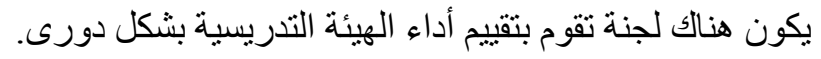
الكلمات الدالة :تطوير المناهج و أعضاء هيئة التدريس و المستفيدين من الخدمة 